\title{
How Forest Management affects Ecosystem Services, including Timber Production and Economic Return: Synergies and Trade-Offs
}

\author{
Philipp S. Duncker ${ }^{1}$, Karsten Raulund-Rasmussen $^{2}$, Per Gundersen ${ }^{2}$, Klaus Katzensteiner ${ }^{3}$, Johnny De Jong ${ }^{4}$, Hans Peter
} $\underline{\text { Ravn }}^{2}, \underline{\text { Mike Smith }}^{5}, \underline{\text { Otto Eckmüllner }}^{3}$ and Heinrich Spiecker $^{l}$

\begin{abstract}
Forest ecosystems deliver multiple goods and services and, traditionally, forest owners tend to have a high interest in goods in the form of merchantable wood. As a consequence, forest management often aims to increase timber production and economic returns through intervention into natural processes. However, forests provide further services, including carbon sequestration, water quantity and quality, and preservation of biodiversity. In order to develop and implement strategies for sustainable forest management, it is important to anticipate the long-term effects of different forest management alternatives on the ability of the forest to provide ecosystem goods and services. Management objectives might emphasize economic interests at the expense of other services. Very few attempts have been made to illustrate and evaluate quantitatively the relationship between forest goods and services. By use of virtual but realistic datasets, we quantified, for multiple services, the effects of five forest management alternatives that form an intensity gradient. Our virtual forest management units represented Central European forest ecosystems in the submontane vegetation zone under a humid-temperate climate with acidic soils. In this zone the European beech (Fagus sylvatica L.) is the dominant tree species. In order to assess the effects on ecosystem services, the untouched natural forest reserve served as a reference. Wherever possible, response functions were deduced to couple the various services via stand-level data to demonstrate trade-offs between the services. Management units comprised all development phases in the sense of a "normal forest". It was clearly illustrated that maximizing the rates of biomass production and carbon sequestration may conflict with protection of authentic biodiversity. Several silvicultural operations may, however, have positive effects on biodiversity and water protection without high costs. We also illustrated that water quality and maintenance of soil fertility may be affected either positively or negatively by several forest management operations. In contrast, water quantity was only minimally influenced by forest management. For the virtual forest in a humid climate, differences of $70 \mathrm{~mm} / \mathrm{yr}$ in runoff were negligible. Under dry continental conditions, however, such differences may have important implications for groundwater formation.
\end{abstract}

Key Words: alternative forest management strategies; biodiversity; carbon sequestration; forest ecosystem services; forest productivity; soil fertility; timber production; water quantity

\section{INTRODUCTION}

Timber production and economic yield are important forestry objectives that are achieved through direct intervention into natural processes. Moreover, forest ecosystems provide a multitude of viable goods and services that are increasingly valued by society (Forest Europe 1993, Millennium Ecosystem Assessment 2005). Accordingly, various models of forest management systems have evolved over time. They range from "exploitive" to "back-to-nature", with all intended to satisfy the diverse human demands on the forest (Seymour and Hunter 1999, Hunter 2001, Gamborg and Larsen 2003). Contemporary sustainable forest management aims to ensure that goods and services derived from forests meet present-day needs while at the same time securing the forests' continued viability and contributions to long-term development. As such, forest management itself requires prudent management in order to conserve essential ecosystem services such as soil fertility and water quality. As well as this, additional supporting and cultural services-such as carbon sequestration, maintenance of biodiversity, or recreational values-also need consideration. One of the most important questions for the future is how to manage the forest for timber production while conserving or improving other important ecosystem services.

In order to develop and implement such strategies, it is important to anticipate the long-term effects of forest management on the status and dynamics of forest ecosystems. Forest management acts through coherent sets of silvicultural operations at the stand level to achieve specific objectives. This implies purposeful manipulation of one or more key variables, e.g., tree species composition, stand density and age structure, and stand edges, or other site attributes that result in a changed ecosystem (Duncker et al. 2012).

Quantifying the effects of forest management on provisioning services, in particular on timber production, has been subject to countless studies. Although empirical studies often face a large number of factors that are difficult to control, these

\footnotetext{
${ }^{1}$ Institute for Forest Growth, Albert-Ludwigs-Universität Freiburg, Germany, ${ }^{2}$ Forest and Landscape Denmark, University of Copenhagen, Denmark, ${ }^{3}$ Department of Forest and Soil Sciences, University of Natural Resources and Life Sciences (BOKU) Vienna, Austria, ${ }^{4}$ Swedish University of Agricultural Sciences, Uppsala, Sweden, ${ }^{5}$ Forest Research, Northern Research Station, Roslin, UK
} 
studies provide solid knowledge for model formulation. Accordingly, scenario modeling aims to describe stand evolution under complex alternative silvicultural regimes. This allows the projection of physical and financial productivity measures (Hasenauer 2006). The ecosystem services considered include biodiversity, soil fertility, carbon storage and sequestration, and water quality and quantity. The corresponding effects of silvicultural operations are then evaluated by using relevant indicators. Because the effects are related to key stand parameters that are influenced by silvicultural operations, they can be integrated into scenario modeling. Thus, scenario modeling further allows the projection and analysis of the effects of forest management alternatives (FMA) on forest ecosystem services.

The relationship between various forest ecosystem services might be synergistic, as has been demonstrated for carbon sequestration and timber production through the transfer of wood carbon from the forest to wood products (Ruddell et al. 2007, Weslien et al. 2009). However, it is also claimed that resulting in situ carbon stock remains less than for stands in unmanaged forests, pointing to a trade-off (Hynynen et al. 2005, Lasch et al. 2005, Seidl et al. 2007, Nunery and Keeton 2010). Several authors have proved the negative effects of intensified forest management on productivity (Sterba 1988, Merganičová et al. 2005, Helmisaari et al. 2011). In addition, biodiversity maintenance may reduce timber production (Boscolo and Vincent 2003). Considering its importance for forest planning, quantified knowledge on synergies and tradeoffs between multiple forest goods and services under different management regimes appears rather limited.

The objective of this study was to reveal synergies and tradeoffs by quantifying the effects of five forest management alternatives on merchantable timber production, land expectation value (LEV), attributes of biodiversity, water quality, water quantity, soil fertility, carbon sequestration, and carbon stock. The analyses of the effects were based on the simulation of a virtual normal forest located in a Central European beech forest vegetation zone. The FMAs ranged from nonintervention to intensive silvicultural systems. Such quantifications are fundamental inputs in decision support and multi-objective forest planning (Pukkala 2002, Lexer and Brooks 2005, Fürstenau et al. 2007).

\section{METHODS}

\section{Site and stands}

The virtual forest management units represented Central European forest ecosystems in a humid-temperate climate with acidic soils. The management units were considered to be located in the southwestern part of Germany, in the submontane vegetation zone around $500 \mathrm{~m}$ above sea level. The soil is a Dystric Cambisol developed on granite/gneiss material. Slight podzolization occurs, in particular under conifers. The sandy loam soil is well drained. For the unmanaged forest nature reserve, a Lignomoder (Zanella et al. 2011) with a 70-mm thickness and a high proportion of deadwood was assumed. In managed beech forests Hemimoder dominate, and in spruce forests Eu-moder is the dominating humus form. Soil physical properties and speciesspecific rooting patterns, both of which are important parameters for hydrological modeling, have been estimated based upon descriptions of soil profiles for soil condition monitoring (BZE) from the Heidelberg region (e.g., BZE_Profil 1035 FA Heidelberg) and model parameters suggested by Federer (1995) for respective soil textural classes. Soil pH is low and the nutrient contents are modest (Table 1). In contrast, nitrogen availability is relatively high mainly due to nitrogen deposition (Table 2) having its origin in cattle farming and industrial emissions. In consequence, soil $\mathrm{C} / \mathrm{N}$ ratios are moderate to low $(<25)$, indicating that soil $\mathrm{N}$ retention would be low or negligible. The suboceanic climate provides for an annual mean precipitation of $1050 \mathrm{~mm}$ and an average air temperature of $8^{\circ} \mathrm{C}$.

It was assumed that the site has been forested since the last glaciations and the potential natural vegetation is a LuzuloFagetum (Ellenberg 1996). The site quality is such that it provides favorable growing conditions that are close to the optimum for European beech. Regional yield classifications provide a site index $\left(\mathrm{H}_{100}\right)$ of $32 \mathrm{~m}$ (top height at age 100 years) for European beech and $35 \mathrm{~m}$ for Norway spruce (Picea abies [L.] Karst.). Accordingly, yield was assumed to be $8 \mathrm{~m}^{3} \mathrm{ha}^{-1}$ $\mathrm{yr}^{-1}$ for beech and $13 \mathrm{~m}^{3} \mathrm{ha}^{-1} \mathrm{yr}^{-1}$ for spruce (Landesforstverwaltung Baden-Württemberg 1993).

\section{Forest management alternatives}

The FMAs were characterized by their objectives and silvicultural approaches, from which essentially coherent sets of forest operational processes at the stand level emerged (Duncker et al. 2012). The FMAs were differentiated by their degree of intervention into natural processes and conditions. In order to analyze the effects of management alternatives on the ecosystem services provided by the virtual forests, five FMAs were defined. The FMAs formed a gradient, from passive to high forest management intensity. The following descriptions of the five FMAs provide the general guidelines for simulating corresponding stand developments.

FMA 1: unmanaged forest nature reserve, in nonintervention forest management

The main objective of an unmanaged forest nature reserve is to allow natural processes, including disturbances and natural cycles, to develop without management intervention to create natural, ecologically valuable, habitats and naturally occurring biodiversity. Thus the forest is kept unmanaged for this sole purpose (Peterken 1996, Sprugel 1991). The nonintervention philosophy is applied in a strict sense. 
Table 1. Soil properties used for generic modeling. ${ }^{\dagger}$

\begin{tabular}{|c|c|c|c|c|c|c|c|c|c|c|c|}
\hline \multicolumn{2}{|c|}{ Horizon } & \multicolumn{2}{|c|}{$\begin{array}{l}\text { Thickness } \\
(\mathrm{mm})\end{array}$} & \multicolumn{2}{|c|}{$\begin{array}{c}\text { Stone fraction } \\
(\%)\end{array}$} & \multicolumn{2}{|c|}{ Texture } & \multicolumn{2}{|c|}{$\begin{array}{c}\text { Porosity } \\
\text { (volume fraction) }\end{array}$} & \multicolumn{2}{|c|}{$\begin{array}{c}\text { Water content } \\
\text { at field capacity } \\
\text { (volume fraction) }\end{array}$} \\
\hline Spruce & Beech & Spruce & Beech & Spruce & Beech & Spruce & Beech & Spruce & Beech & Spruce & Beech \\
\hline $\mathrm{O}$ & $\mathrm{O}$ & 80 & 30 & 0 & 0 & - & - & 0.9 & 0.9 & 0.3 & 0.3 \\
\hline $\mathrm{Ae}$ & $\mathrm{Ah}$ & 50 & 120 & 10 & 10 & Sandy loam & Sandy loam & 0.55 & 0.6 & 0.25 & 0.25 \\
\hline Bs & $\mathrm{Bw}$ & 70 & 530 & 10 & 25 & Loamy sand & Sandy loam & 0.6 & 0.55 & 0.25 & 0.25 \\
\hline $\mathrm{Bw}$ & $\mathrm{Cw}$ & 530 & 350 & 25 & 50 & Sandy loam & Loamy sand & 0.5 & 0.4 & 0.2 & 0.2 \\
\hline $\mathrm{Cw}$ & & 350 & & 50 & & Loamy sand & & 0.4 & & 0.2 & \\
\hline \multicolumn{2}{|c|}{ Horizon } & \multicolumn{2}{|c|}{$\begin{array}{c}\mathrm{pH} \\
\left(\mathrm{CaCl}_{2}\right)\end{array}$} & \multicolumn{2}{|c|}{ (mg.g ${ }^{-1}$ DM) } & \multicolumn{2}{|c|}{$\mathrm{C} / \mathrm{N}$ ratio } & \multicolumn{2}{|c|}{$\underset{\left(\mathrm{mmol}^{\mathrm{kgg}}\right.}{\mathrm{CEC}}$} & \multicolumn{2}{|c|}{$\begin{array}{c}\text { Base saturation } \\
(\%)\end{array}$} \\
\hline Spruce & Beech & Spruce & Beech & Spruce & Beech & Spruce & Beech & Spruce & Beech & Spruce & Beech \\
\hline $\mathrm{O}$ & $\mathrm{O}$ & 3.5 & 4.2 & 300 & 350 & 25 & 25 & 170 & & 15 & \\
\hline $\mathrm{Ae}$ & $\mathrm{Ah}$ & 3.8 & 4.2 & 30 & 50 & 20 & 18 & 120 & 100 & 9 & 15 \\
\hline Bs & $\mathrm{Bw}$ & 4.2 & 4.5 & 15 & 20 & 18 & 10 & 100 & 60 & 10 & 10 \\
\hline $\mathrm{Bw}$ & $\mathrm{Cw}$ & 4.5 & 4.5 & 10 & 7 & 15 & 5 & 70 & 50 & 15 & 15 \\
\hline $\mathrm{Cw}$ & & 4.8 & 4.8 & 5 & & 10 & & 60 & & 18 & 20 \\
\hline
\end{tabular}

Topography: slope $10 \%$, aspect $\mathrm{W}$, elevation $500 \mathrm{~m}$ asl, freely draining soil.

FMA 2: close-to-nature forestry, in low-intervention European beech management

The objective is to produce valuable timber while using the emulation of natural processes as a guiding principle. Biological legacies and natural biotopes, as well as habitat trees, are promoted inside the stand and should not be removed. European beech was chosen for timber production because this is the dominant tree species in the potential natural vegetation. The preferred method of regeneration is natural regeneration. The final harvesting system is a target diameter harvest of individual trees over a period of 40 years in order to initiate natural regeneration of beech. The target is $65 \mathrm{~cm}$ diameter at breast height $(\mathrm{dbh})$, which shall be reached with 60 future crop trees/ha. Due to the risk of red heartwood formation, the target diameter is to be reached within 120 years. The future crop trees are released in thinnings from above. Only trunks are allowed to be extracted from the site. Habitat and biodiversity protection are incorporated by selecting single and small groups of trees to be left in the stand. The unmanaged areas will have implications for forest operation processes. They increase the risk of falling dead trees or branches, and potentially require longer skidding distances. This leads to higher harvesting costs, which are difficult to quantify. Instead, we calculated the full timber losses for the remaining trees, although in practical forestry those trees are often low quality, damaged, or nonproductive trees, or they are rare species, are in a special habitat, or are veteran trees. This was implemented in the model as leaving $20 \%$ of the area unmanaged.
FMA 3: combined-objective forestry, in mediumintervention European beech and Norway spruce management

The objectives are combined, emphasizing economic return while respecting other ecosystem services. Contrary to lowintervention (close-to-nature) forestry, Norway spruce is admixed on $50 \%$ of the area for economic purposes. Mixture type is group-wise to promote self-pruning processes in beech. The preferred method of regeneration is natural regeneration. The final harvesting system is a target diameter harvest in the form of a group harvest, over a period of 20 years. The target diameter for beech is $55 \mathrm{~cm}$, to be reached with 100 future crop trees/ha. For spruce the target diameter is $50 \mathrm{~cm}$, to be achieved with 150 future crop trees/ha. The future crop trees are released in thinnings from above, starting at a top height of $12 \mathrm{~m}$. Due to the risk of red heartwood formation, the target diameter is to be reached in beech within 120 years. Only trunks and pole-sized solid wood are utilized and extracted from the site. Habitat and biodiversity protection are incorporated by leaving $5 \%$ of the area unmanaged, mainly by leaving all deadwood, big trees (beech $>100 \mathrm{~cm} \mathrm{dbh}$ ), old trees ( $>150$ years), trees with holes, and unusual tree species. The practical implications on forest operations are accounted for as described above for FMA 2.

\section{FMA 4: even-aged forestry, in high intervention Norway spruce management}

The main objectives of even-aged forestry are to produce timber and profit. If ecological aims can be achieved without much loss of revenue, they are normally incorporated. In many European countries, national guidelines outline the best 
Table 2. Deposition (open field) and storage of nutrients in the top $100 \mathrm{~cm}$ of the soil profile. ${ }^{\dagger}$

\begin{tabular}{|c|c|c|c|}
\hline \multirow[b]{2}{*}{ Nutrient } & \multicolumn{3}{|c|}{ Deposition } \\
\hline & $\underset{\left(\mathrm{kg} \mathrm{ha}^{-1} \mathrm{yr}^{-1}\right)}{\text { Beech }}$ & $\begin{array}{c}\text { Spruce } \\
\left(\mathrm{kg} \mathrm{ha}^{-1} \mathrm{yr}^{-1}\right)\end{array}$ & $\begin{array}{l}\text { Soil storage to } \\
\text { a } 1-\mathrm{m} \mathrm{depth}^{-1} \\
\left(\mathrm{~kg} \mathrm{ha}^{-1}\right)\end{array}$ \\
\hline $\mathrm{N}$ & $20(17)$ & $30(25)$ & 6000 \\
\hline $\mathrm{P}$ & $0.5(0.2)$ & $0.7(0.3)$ & 300 \\
\hline $\mathrm{K}$ & $5(2)$ & $7(3)$ & 250 \\
\hline $\mathrm{Ca}$ & $8(2.7)$ & $10(4)$ & 400 \\
\hline $\mathrm{Mg}$ & $1.0(0.7)$ & $1.2(1.0)$ & 150 \\
\hline
\end{tabular}

${ }^{\dagger}$ Amounts were based on typical amounts in the region as assessed at Level II plot 802 Heidelberg run by Forstliche Versuchs- und Forschungsanstalt Baden-Württemberg.

practices for ensuring that operations in this approach are compatible with sustainability and environmental protection. Norway spruce is planted at a density of 3000 trees/ha. The final harvesting systems used are strip-wise clearings or smallscale clearcuts once the economic objective is maximized, that is, land expectation value at a $3 \%$ interest rate. Around 250 trees are released by heavy thinning from below. Only trunks, pole-sized stems, and larger solid wood are utilized and extracted from site.

\section{FMA 5: wood biomass production, in intensive intervention} Norway spruce management

Using even-aged management, the main aims are to maximize the production of saw logs for the construction market, as well as woody residue for the woodfuel market. The latter is achieved by thinning small-diameter stems. Site preparation and planting will be the normal methods of regeneration, with chemical weed control being used as required. Planting density and thinning regime are considered to be identical to that in FMA 4 in order to facilitate cross comparison. However, in addition to the solid wood harvesting practiced in FMA 4, about $80 \%$ of the branches, needles, and woody tops (slash) are chipped and utilized as woodfuel. Patch clear felling is the normal silvicultural practice.

\section{Growth, production, and economic value}

The actual growth of beech and spruce managed under the different approaches was modeled with W+ (Yue et al. 2008), which is a forest growth simulator based on a combined standlevel and individual tree-level growth model for even-aged forests. Its parameters are estimated from permanent plots of experimental thinning located in southwestern Germany. The plots cover a wide range of site types and growing conditions. Further, a wide range of different treatments is included with respect to initial spacing, type of thinning, and thinning intensity. The simulator $\mathrm{W}+$ is intended for use as a silvicultural decision support tool (Weise and Kublin 1997, 1998). Yue et al. (2008) describe the concept in detail and provide a comprehensive evaluation.

Besides site index and stand age, the input data for the model consisted of a list of sample trees with their dbh and height.
Where empirical data on sample trees were missing, Johnson curves (Elderton and Johnson 1969) were used to generate diameter distribution based on stem number, basal area, age, and mean height. This option to generate stands was applied to initialize forest stands. Stand development under the treatment regimes of the five FMAs was modeled for a complete rotation. The annual stages of stand development were split into age cohorts which were assumed to represent individual stands in a virtual normal forest. Because rotation lengths differed between the FMAs, in order to enable crosscomparisons, the size of every age cohort of the stand development had to be scaled so that their sum equaled a standard normal forest area. This approach was directly applicable for FMAs 4 and 5, where the stands were harvested in final clearings. In contrast, FMAs 2 and 3 implied a prolonged period of regeneration cuttings that were intended to stimulate natural regeneration. In these cases, regeneration was assumed to establish and develop under the canopy of the preceding stand. Accordingly, the same forest area was used by two age cohorts, one from each generation. This was accounted for by allotting the area only to the generation that formed the main canopy, while no area needed to be dedicated to regeneration as long as it was in the shade of the former one. It was assumed that the phase of two overlapping generations accounted for half of the prolonged period of regeneration cuttings in final harvesting. For that reason the rotation length for FMAs 2 and 3 was shortened by half of this period before allocating the reference normal area to the age cohorts (Assmann 1961). In the case of FMA 1, no production target or stand treatment was defined. Nonetheless, the approach chosen for cross comparing the FMAs required a mean stand life. Thus, it was assumed that a new small-scale generation is able to establish under the canopy of the preceding stand as soon as the basal area of the preceding stand is permanently reduced by tree mortality to $<20 \mathrm{~m}^{2} \mathrm{ha}^{-1}$. Stand development and tree mortality were estimated with the $\mathrm{W}+$, and the assumption led to a mean stand life of 163 years. It should be noted that the mortality model of $\mathrm{W}+$ is sensitive to stand density and tree dimension. However, it does not have any disturbance model built in to account for bark beetles, storms, or breakage due to snow load. 
The productive service of the forest was assessed in terms of the amount of merchantable wood volume produced-i.e., solid stemwood, plus in the case of beech, branches $>7 \mathrm{~cm}$ diameter over bark at the smaller end. The FMAs were compared in terms of the mean annual increment $\left(\mathrm{MAI}_{u}\left(\mathrm{~m}^{3}\right.\right.$ $\mathrm{ha}^{-1} \mathrm{yr}^{-1}$ )) being the gross yield of wood volume per hectare at the end of the rotation divided by length of rotation. In addition, land expectation values sensu Faustmann (1849a and b) were calculated to assess the economic yield from wood production in the management alternatives. Land expectation value is a common discounted cash flow method applied to value timberland (Straka and Bullard 1996) and was calculated for interest rates from 1 to $5 \%$. The cash flows integrated in land expectation value resulted from forestry operations, e.g., planting, tending, thinning, or harvesting. Applied planting costs for spruce in FMAs 4 and 5 were 2,300 $€ \mathrm{ha}^{-1}$. Tending costs were $500 € \mathrm{ha}^{-1}$ at ages 5 and 15 . The cash flows for thinning or harvesting operations were estimated by sum-ofproducts of volume and net return $/ \mathrm{m}^{3}$ of harvested trees. The net revenue $/ \mathrm{m}^{3}$ at roadside for medium-quality roundwood, according to the average for the period 1995 to 2005, was described as a function of dbh and is provided in Fig. 1 (Duncker and Zell 2009). Chip residues incurred in FMA 5 were assumed to provide for a net revenue at roadside of $5 € /$ loose $\mathrm{m}^{3}$. Fixed costs were not considered in the land expectation value calculation; accordingly, the land expectation value is zero for FMA 1 as well as for the set-aside areas, which were proportionally accounted for in FMAs 2 and 3.

Fig. 1. Net revenue $\left(€ / \mathrm{m}^{3}\right)$ as a function of $\mathrm{dbh}$, for Norway spruce (solid line) and European beech (dashed line), medium-quality wood at roadside based on average values for the period 1995 to 2005 (Duncker and Zell 2009).

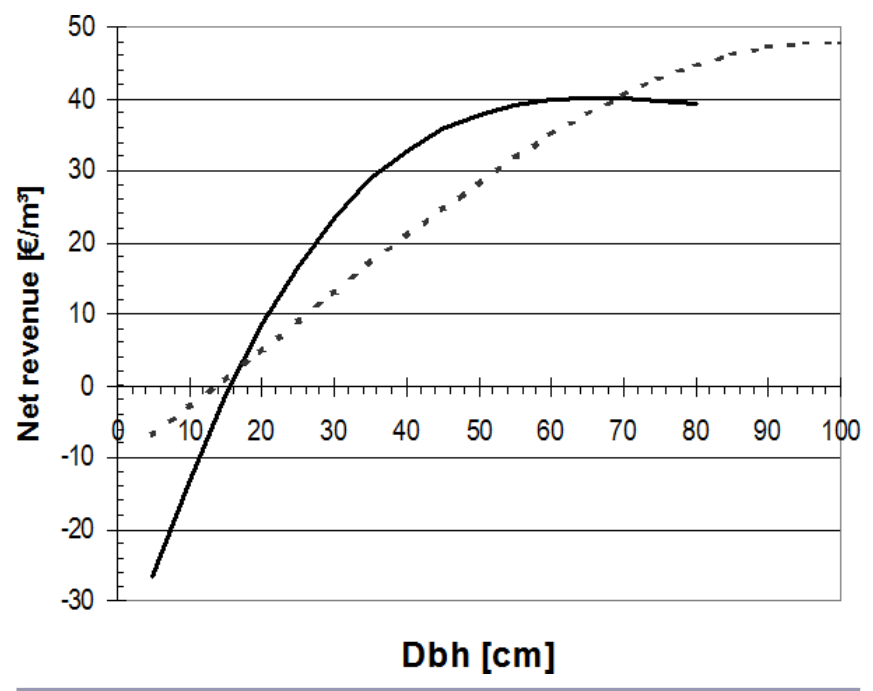

\section{Carbon}

Carbon stocks and sequestration were obtained by converting the volume growth-which referred to solid wood, as estimated with $\mathrm{W}+$ - to total net biomass growth $\left(\mathrm{NG}_{\text {total }}\right)$ (Pretzsch 2009), using generic biomass functions for spruce (Wirth et al. 2004, Eckmüllner 2006) and beech (Wutzler et al. 2008). These functions were applied to estimate dry mass in different tree components, i.e., foliage, branch, stem, and root biomass respectively, based on individual tree and stand variables. Mean annual carbon sequestration rates were calculated on the basis of $\mathrm{NG}_{\text {total }}$ within the FMAs to account for respiration and ephemeral losses of biomass as trees grow. It is expressed as mean annual carbon sequestration in dendro biomass per hectare $\left(\mathrm{t}_{\mathrm{C}} \mathrm{ha}^{-1} \mathrm{yr}^{-1}\right)$. It is generally assumed that carbon accounts for 50\% of biomass (Knigge and Schulz 1966).

While the annual amount of harvested carbon within the FMAs was the sum of carbon in all extracted biomass over a rotation divided by mean length of the rotation, mean carbon stock per hectare was estimated as the total sum of carbon in dry masses for the different above-ground tree components divided by mean length of rotation. Mean carbon stock in dead biomass was estimated by multiplying the mean amount of deadwood by a mean carbon density of $122 \mathrm{~kg} \mathrm{~m}^{-3}$ in deadwood (Vesterdal and Christensen 2007). The accrued amount of deadwood itself was simulated with the mortality model implemented in W+ (Yue et al. 2008). Further, harvesting residues left on site, i.e., stumps, branches, and tree tops, were added in case of stemwood harvesting only. The coarse woody debris was split into two fractions, i.e., basically solid stemwood, $>10 \mathrm{~cm}$ diameter; and remaining above-ground biomass, usually $<10 \mathrm{~cm}$. The mean amount of coarse woody debris in each fractions was calculated as the dynamic equilibrium of the mean annual accrued amount of deadwood and the constant decay rates (Zell et al. 2009). These decay rates were estimated for each deadwood fraction and tree species, with a mixed model. This mixed model included July temperature and annual precipitation as input variables and thus had the advantage of being site specific (Zell et al. 2009). Annual ephemeral losses of twigs and branches were not considered.

\section{Water}

To visualize the effects of tree species, rotation length, and thinning regime, the hydrological model BROOK90 (Federer 1995) was used to calculate water balances for the generic forest management alternatives. Parameterization was based upon experiments with spruce and beech in which the model was thoroughly tested (e.g., Katzensteiner 2000, Jost et al. 2005). For beech, leaf area (single sided, projected) was calculated for the different development stages according to Hietz et al. (2010). For spruce, leaf area was estimated from needle mass using a variation of specific leaf area depending on tree class (Eckmüllner and Sterba 2000). Maximum canopy 
conductance per unit leaf area was set at $0.25 \mathrm{~cm} \mathrm{~s}^{-1}$ for spruce and $0.45 \mathrm{~cm} \mathrm{~s}^{-1}$ for beech. Albedo was set to 0.14 for spruce and 0.20 for beech. For snow cover, albedo was set to 0.23 (spruce) and 0.3 (beech). To simulate the effects of clearcut and herbaceous vegetation in the clearcut phase of spruce in FMAs 4 and 5, the following were assumed, according to Katzensteiner (2000): a decreasing conductance from 0.4 to $0.25 \mathrm{~cm} \mathrm{~s}^{-1}$ in the first 10 years, and an increasing albedo from 0.15 to 0.23 in the first 4 years, decreasing then to 0.14 over the next 6 years. For the clearcut stage in FMA 5, assuming bare soil in Years 1 and 2, leaf area index was set to 0.1 , and albedo was allowed to increase from 0.05 in Year 1 to 0.15 in Year 10.

A 10-year time series of daily weather records was developed for the years 1997 to 2006. ${ }^{1}$ Thus a consistent datasetincluding information on precipitation, radiation, temperature, vapor pressure, and wind speed, and including both dry and wet years-could be used for further modeling. The 10-year time series was repeated over the rotation and thus applied to every stand development stage (year) for every forest management alternative. The reactions of mixed stands were calculated as a weighted average of the output for the respective development stages of pure stands.

We used $\mathrm{NO}_{3}^{-}$concentration in the water, leaving the root zone as an indicator for impact on water quality (Gundersen et al. 2006) because high $\mathrm{NO}_{3}^{-}$concentrations are not desirable in surface and ground water. Furthermore, $\mathrm{NO}_{3}^{-}$ leaching contributes to soil acidification, and in acid soils $\mathrm{NO}_{3}{ }^{-}$concentrations correlate with concentrations of plant toxic aluminum $\left(\mathrm{Al}^{3+}\right)$ and some heavy metals (Gundersen et al. 2006). The $\mathrm{NO}_{3}^{-}-\mathrm{N}$ concentration was calculated based on a rotation-scale $\mathrm{N}$ mass balance, i.e., the cumulative input of $\mathrm{N}$ over the rotation minus the cumulative removal of $\mathrm{N}$ in harvested products divided by the volume of water draining the stand as estimated above (N-dep-N-removal)/runoff. This implies that the incorporation of $\mathrm{N}$ in soil organic matter over the rotation was negligible, which is expected with the mineral soil $\mathrm{C} / \mathrm{N}$ ratio being below 20 at the site (Gundersen et al. 1998). The calculated $\mathrm{NO}_{3}^{-}-\mathrm{N}$ concentration will likely approximate the concentration observed in mature stands (about Year 20 to harvest) and will also be a reasonable estimate for the average $\mathrm{NO}_{3}{ }^{-}$concentration over the whole rotation (Gundersen et al. 2006).

\section{Nutrients and acidification}

The amount of nutrient removed through harvesting was estimated by multiplying the average nutrient concentrations in different tree components and in their corresponding dry masses (Jacobsen et al. 2002). Average annual nutrient export was calculated for the harvested stemwood including bark. In addition, for spruce FMA 5, the nutrient content within exported harvest residues was assumed to be $80 \%$ of foliage and branches. For beech in FMA 2, the export was proportionally reduced by the area set aside for conservation $(20 \%)$.

Inputs to the systems originating from deposition were based on typical amounts in the region.- It was assumed that the inputs to spruce were 1.5 times the inputs to beech (Table 2). To illustrate the effects of harvesting, and of beech versus spruce, in the various FMAs, deposition minus export was calculated. The acidifying effects of biomass harvesting was estimated as the sum of calcium, magnesium, and potassium on an equivalence basis (Raulund-Rasmussen et al. 2008). Nitrate leaching is accompanied by cations, usually the socalled base-cations, and therefore responsible for soil acidification (Gundersen et al. 2006). Leaching of nitrate was therefore designated potential acidification.

\section{Biodiversity}

There have been many attempts to find methods to evaluate the biodiversity of different forests (Gustafsson et al. 1999, Larsson 2001). Because it is impossible to measure and monitor the effects of various management practices on all species, indicators, serving as surrogates for total biodiversity, are used (Lindenmayer et al. 2000). However, biodiversity cannot be described in simple figures and designing proper indicators is a difficult task (Failing and Gregory 2003). Because this study is based on simulations instead of real inventories, we concentrated on attributes that are well known for supporting high levels of biodiversity. Also, the attributes chosen were adequately characterized in tree-level and standlevel modeling (Lexer et al. 2000). The selected attributes in our study were: abundance of deadwood in the form of fine and coarse woody debris; density of large-diameter trees; number of tree species; and area of woodland key habitats, which in our case was the same as the set-aside area.

\section{Multivariate analysis}

For each of the key services discussed above a subset of 2 to 4 indicators (total 13) was chosen for inclusion in a principal component analysis. Thus, the principal component analysis gave a balanced weight to each service. We considered only two dimensions because the two first principal components captured almost $90 \%$ of the variability in the chosen 13 indicators across the FMAs. We used SAS 9.1 for the analysis.

\section{RESULTS}

The results are summarized in Table 3 which illustrates the effects of the FMAs for all indicators.

\section{Wood volume production and land expectation value}

Productivity by definition was set to zero in FMA 1, i.e., respiration at the ecosystem level and production balanced each other. The wood volume production, as expressed in $\mathrm{MAI}_{\mathrm{u}}$ at the stand level, was highest in spruce FMAs 4 and 5 and lowest in beech FMA 2 (Table 4). MAI in beech FMA 2 accounted for about $54 \%$ - or $68 \%$ if only the managed part is considered-compared to spruce FMAs 4 and 5. Due to 
Table 3. Effects of the forest management alternatives (FMAs) on multiple forest ecosystem services.

\begin{tabular}{|c|c|c|c|c|c|}
\hline Productive functions & $\begin{array}{r}\text { FMA 1, } \\
\text { nature reserve }\end{array}$ & $\begin{array}{r}\text { FMA 2, } \\
\text { low intervention }\end{array}$ & $\begin{array}{r}\text { FMA 3, } \\
\text { mixed approach }\end{array}$ & $\begin{array}{r}\text { FMA 4, } \\
\text { timber }\end{array}$ & $\begin{array}{l}\text { FMA 5, } \\
\text { biomass }\end{array}$ \\
\hline $\begin{array}{l}\text { Mean annual increment } \\
\left(\text { merchantable } \mathrm{m}^{3} \mathrm{ha}^{-1} \mathrm{yr}^{-1}\right)\end{array}$ & 0 & 8 & 10 & 14 & 14 \\
\hline \multicolumn{6}{|l|}{ Land expectation value (LEV) } \\
\hline $1 \%\left(€ \mathrm{ha}^{-1}\right)$ & 0 & 10630 & 16492 & 19232 & 21771 \\
\hline $2 \%\left(€ \mathrm{ha}^{-1}\right)$ & 0 & 2641 & 4955 & 4237 & 5427 \\
\hline $3 \%\left(€ \mathrm{ha}^{-1}\right)$ & 0 & 601 & 1734 & 64 & 783 \\
\hline $4 \%\left(€ \mathrm{ha}^{-1}\right)$ & 0 & -73 & 512 & -1523 & -1050 \\
\hline $5 \%\left(€ \mathrm{ha}^{-1}\right)$ & 0 & -303 & 2 & -2180 & -1856 \\
\hline \multicolumn{6}{|l|}{ Carbon } \\
\hline $\mathrm{C}$ stock living (tons $\mathrm{C} \mathrm{ha}_{1}^{-1}$ ) & 177 & 112 & 85 & 97 & 97 \\
\hline $\mathrm{C}$ stock dead (tons $\left.\mathrm{C}^{-1}{ }_{1}^{-1}\right)$ & 20 & 6 & 5 & 6 & 1 \\
\hline $\mathrm{C}$ harvested (tons $\mathrm{C} \mathrm{ha}^{-1} \mathrm{yr}^{-1}$ ) & 0 & 2,1 & 2,3 & 2,7 & 3.5 \\
\hline $\begin{array}{l}\mathrm{C} \text { assimilated (tons } \mathrm{C} \mathrm{ha}^{-1} \mathrm{yr}^{-1} \text { ) (based on } \\
\mathrm{NG}_{\text {total }}^{\dagger} \text { ) }\end{array}$ & 4.5 & 3.9 & 3.7 & 4.2 & 4.2 \\
\hline \multicolumn{6}{|l|}{ Nutrients / acidification } \\
\hline $\begin{array}{l}\mathrm{N} \text { deposition }- \text { harvesting } \\
\left(\mathrm{kg} \mathrm{ha}^{-1} \mathrm{yr}^{-1}\right)\end{array}$ & 17 & 10 & 14 & 18 & 6 \\
\hline $\begin{array}{l}\mathrm{P} \text { deposition }- \text { harvesting } \\
\left(\mathrm{kg} \mathrm{ha}^{-1} \mathrm{yr}^{-1}\right)\end{array}$ & 0.2 & -0.4 & -0.4 & -0.5 & -1.8 \\
\hline $\begin{array}{l}\mathrm{K} \text { deposition }- \text { harvesting } \\
\left(\mathrm{kg} \mathrm{ha}^{-1} \mathrm{yr}^{-1}\right)\end{array}$ & 2.0 & -2.4 & -1.8 & -1.1 & -6.4 \\
\hline $\begin{array}{l}\text { Ca deposition - harvesting } \\
\left(\mathrm{kg} \mathrm{ha}^{-1} \mathrm{yr}^{-1}\right)\end{array}$ & 2.7 & -5.0 & -4.3 & -3.6 & -10 \\
\hline $\begin{array}{l}\text { Mg deposition - harvesting } \\
\left(\mathrm{kg} \mathrm{ha}^{-1} \mathrm{yr}^{-1}\right)\end{array}$ & 0.7 & -0.4 & 0.2 & 0 & -0.9 \\
\hline $\begin{array}{l}\text { Acidification due to harvesting } \\
\left(\mathrm{kmol} \mathrm{H}^{+} \text {eqv ha }{ }^{-1} \mathrm{yr}^{-1}\right)\end{array}$ & 0 & 0.6 & 0.6 & 0.6 & 1.1 \\
\hline $\begin{array}{l}\text { Potential acidification due to nitrate leaching } \\
\left(\mathrm{kmol} \mathrm{H}^{+} \text {eqv } \mathrm{ha}^{-1} \mathrm{yr}^{-1}\right)\end{array}$ & 1.2 & 0.7 & 1.0 & 1.3 & 0.4 \\
\hline \multicolumn{6}{|l|}{ Water } \\
\hline Runoff $^{*}\left(\mathrm{~mm} \mathrm{yr}^{-1}\right)$ & 579 & 622 & 622 & 556 & 557 \\
\hline Nitrate in runoff ( $\left.\mathrm{mg} \mathrm{NO}_{3}--\mathrm{N} \mathrm{l}^{-1}\right)$ & 2.9 & 1.6 & 2.3 & 3.3 & 1.2 \\
\hline \multicolumn{6}{|l|}{ Biodiversity } \\
\hline \multicolumn{6}{|l|}{ Woody debris } \\
\hline Fine $\left(\mathrm{m}^{3} \mathrm{ha}^{-1}\right)$ & 34 & 25 & 36 & 46 & 11 \\
\hline Coarse $\left(\mathrm{m}^{3} \mathrm{ha}^{-1}\right)$ & 129 & 26 & 7 & 0 & 0 \\
\hline \multicolumn{6}{|l|}{ Trees, average dbh } \\
\hline$>40 \mathrm{~cm}\left(\mathrm{~N} \mathrm{ha}^{-1}\right)$ & 44 & 36 & 41 & 51 & 51 \\
\hline$>60 \mathrm{~cm}\left(\mathrm{~N} \mathrm{ha}^{-1}\right)$ & 21 & 10 & 5 & 1 & 1 \\
\hline$>70 \mathrm{~cm}\left(\mathrm{~N} \mathrm{ha}^{-1}\right)$ & 15 & 4 & 1 & 0 & 0 \\
\hline$>80 \mathrm{~cm}\left(\mathrm{~N} \mathrm{ha}^{-1}\right)$ & 11 & 2 & 0 & 0 & 0 \\
\hline$>100 \mathrm{~cm}\left(\mathrm{~N} \mathrm{ha}^{-1}\right)$ & 6 & 1 & 0 & 0 & 0 \\
\hline Trees, number of species & 7 & 7 & 2 & 1 & 1 \\
\hline
\end{tabular}
$\left(\mathrm{N} \mathrm{ha}^{-1}\right)$

${ }^{\dagger}$ Net growth $\left(\mathrm{NG}_{\text {total }}\right)$ is defined here as net total biomass growth $\left(\mathrm{t}_{\mathrm{C}} \mathrm{ha}^{-1} \mathrm{yr}^{-1}\right)$ without continuous losses of foliage, branch, or root biomass as trees grow.

${ }^{\ddagger}$ Mean annual precipitation was $1050 \mathrm{~mm} \mathrm{yr}^{-1}$. Evapotranspiration is the difference between precipitation and runoff.

beech and spruce having different wood densities, the FMAs did not show large differences in mean annual net biomass growth $\left(\mathrm{NG}_{\text {total }}\right)$. Here, the productivity in beech FMA 2 accounted for $92 \%$ of the highest $\mathrm{NG}_{\text {total }}$ achieved in spruce FMAs 4 and 5 (Table 4). The ranking of FMAs in terms of land expectation value was strongly sensitive to the interest rate and only coincided with corresponding volume productivity at low interest rates (Table 4). Despite the fact that FMA 4 produced the most wood volume, it also produced the lowest land expectation value when the interest rate was $>2 \%$. As demonstrated in FMA 5, additional extraction of harvesting residues for woodfuel could only compensate for this effect up to an interest rate of $3 \%$. As soon as the interest rate exceeded $2 \%$, the combined beech and spruce FMA 3 was favorable in providing the highest land expectation values. In contrast to all the other management alternatives, it remained positive, even for an interest rate of $5 \%$.

\section{Carbon storage and export}

The carbon stock in living biomass was clearly largest in the untouched forest reserve (FMA 1) due to the no-harvesting regime, whereas the other FMAs showed only minor 
Table 4. Productivity measures for the forest management alternatives, at the stand level.

\begin{tabular}{|c|c|c|c|c|c|c|c|c|c|}
\hline \multirow[b]{2}{*}{ Species } & \multirow[b]{2}{*}{$\begin{array}{l}\text { Management } \\
\text { approach }\end{array}$} & \multirow[b]{2}{*}{$\begin{array}{l}\text { Prod. time } \\
\quad(y r)\end{array}$} & \multirow[b]{2}{*}{$\begin{array}{c}\mathrm{NG}_{\text {total }} \\
\left(\mathrm{t}_{\mathrm{C}} \text { ha }\right. \\
\left.\mathrm{yr}^{-1}\right)\end{array}$} & \multirow[b]{2}{*}{$\begin{array}{c}\mathrm{MAI}_{\underline{\mathrm{u}}}^{\ddagger} \\
\left(\mathrm{m}^{3} \mathrm{ha}^{-1}\right. \\
\left.\mathrm{yr}^{-1}\right)\end{array}$} & \multicolumn{5}{|c|}{ Land expectation value } \\
\hline & & & & & $\left(€ \mathrm{ha}^{\mathrm{i}}{ }^{\mathrm{i}} \mathrm{yr}^{-0.01}\right)$ & $\left(€ \mathrm{ha}^{-1} \mathrm{yr}^{-1}\right)$ & $\begin{array}{r}\mathrm{i}=0.03 \\
\left(€ \mathrm{ha}^{-1} \mathrm{yr}^{-1}\right)\end{array}$ & $\left(€ \mathrm{ha}^{-1} \mathrm{yr}^{-1}\right)$ & $\left(€ \mathrm{ha}^{-1} \mathrm{yr}^{\mathrm{i}}=0.05\right)$ \\
\hline Spruce & FMA 5 & 81 & 4.2 & 13.9 & 21,771 & 5,427 & 783 & $-1,050$ & $-1,856$ \\
\hline Spruce & FMA 4 & 81 & 4.2 & 13.9 & 19,232 & 4,237 & 64 & $-1,523$ & $-2,180$ \\
\hline Spruce & FMA 3 & 84 & 3.4 & 11.1 & 21,273 & 7,107 & 2,874 & 1,113 & 298 \\
\hline Beech & FMA 3 & 120 & 3.9 & 9.9 & 13,448 & 3,325 & 777 & -36 & -294 \\
\hline Beech $^{\S}$ & $F M A 2(m g d)$ & 118 & 3.7 & 9.4 & 13,288 & 3,301 & 751 & -92 & -379 \\
\hline Beech & FMA 2 & $118^{\S}$ & 3.9 & 7.5 & 10,630 & 2,641 & 601 & -73 & -303 \\
\hline
\end{tabular}

differences (Table 3). The amount of carbon stored in dead biomass was similar for each of FMAs 2, 3 and 4, but was significantly greater in the reserve due to no harvesting and was clearly less in FMA 5 due to the removal of residues. The mean annual carbon sequestration rates were almost similar for all five FMAs, whereas carbon removal by means of harvesting increased significantly from FMA 1 to 5-i.e., from none in the reserve to, in FMA 5, an amount almost corresponding to that stored in stemwood, branches, and needles. The difference between net assimilated carbon and harvested carbon remained in the ecosystem for decomposition and some ends up in soil humus. The storage of harvested carbon in wood products and the substitution of fossil carbon by the harvested carbon were not considered.

\section{Water}

Table 3 provides the average values over the rotation length of the water consumed (evapotranspiration) and seepage below the rooting zone (Q). Due to the cool humid climate, with high precipitation rates and low evaporative demand, there was a water surplus of around $600 \mathrm{~mm} \mathrm{yr}^{-1}$ and only minor relative differences between the FMAs. The least runoff occurred in FMAs 4 and 5 due to the higher evapotranspiration loss of spruce compared to beech. The nature reserve FMA 1 had less runoff than the two other beech alternatives (FMAs 2 and 3) due to an absence of clearcut regeneration characterized by high runoff. At the scale of single forest stands there was a clear relationship between water consumption and stand age, stand structure, and leaf area (Fig. 2).

Water quality, indicated by nitrate concentrations in seepage below the rooting zone, was little affected by the FMAs. Estimated concentrations ( 1.2 to $3.3 \mathrm{mg} \mathrm{N}^{-1}$, Table 3 ) were well below the drinking water standard at $11 \mathrm{mg} \mathrm{N}^{-1}(50 \mathrm{mg}$ $\mathrm{NO}_{3}^{-} 1^{-1}$ ) because of the relatively high seepage amount in the region studied. Because the seepage amounts varied only about $10 \%$ among the FMAs, the differences in nitrate concentrations mainly reflected the differences in $\mathrm{N}$ surplus among the FMAs (6 to $18 \mathrm{~kg} \mathrm{~N} \mathrm{ha}^{-1} \mathrm{yr}^{-1}$, Table 3).

Fig. 2. Relationships between stand age, leaf area index (LAI) development, and evapotranspiration (EIT = sum of soil and intercepted rain evaporation and transpiration) for single stands of spruce (FMA 4) and beech (FMA 2).

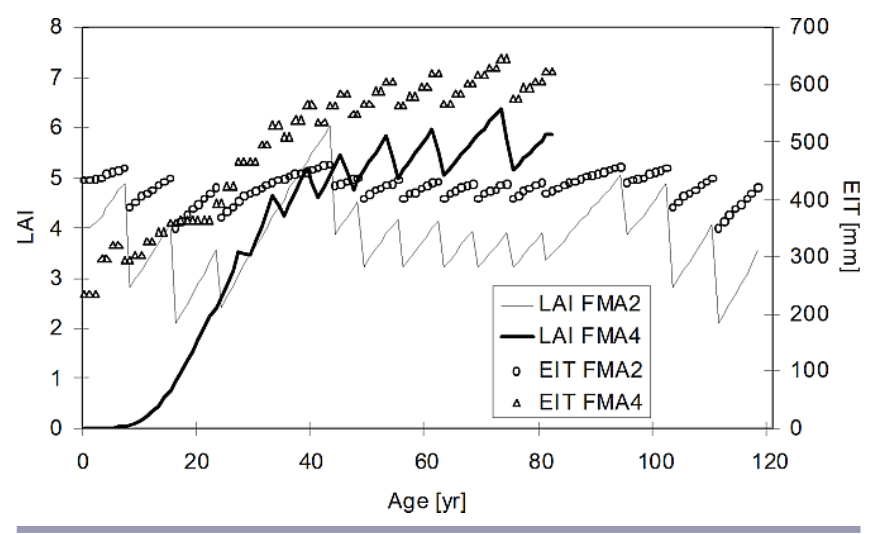

\section{Nutrients and acidification}

For all FMAs more nitrogen was deposited than was exported in harvested products. The surplus was related to tree species for which spruce had a higher surplus than beech due to higher deposition rates in spruce stands (Table 2), and due to the degree of harvesting for which there was an especially high surplus in the reserve and a low surplus in the very intensive FMA5. The other elements all showed higher export, due to harvesting rather than deposition, except for the reserve where a small positive balance was seen for all elements. This was especially the case in the very intensive FMA 5 which shows much higher export than deposition. The acidification due to harvesting was of equal size in FMAs 2, 3, and 4 whereas the intensive FMA 5 showed almost double the acidification rate. 
No acidification due to harvesting took place in the unmanaged reserve. Acidification also took place when nitrate was leached (Gundersen et al. 2006), and therefore the highest acidification due to nitrate leaching took place in the reserve (FMA 1) and in the spruce alternatives (FMAs 4 and 5). Summing the two contributions showed increasing acidification from FMA 1 to FMA 5 (Table 3).

\section{Biodiversity}

There was a steep decrease in the attributes of biodiversity from FMA 1 to FMAs 4 and 5 (Table 3). The abundance of fine woody debris did not decrease with management intensity, because thinning with extraction of solid wood created large amounts of fine deadwood in the managed forest only. However, the best measure of biodiversity values is in general connected with coarse woody debris. While the amount of coarse woody debris in FMA 2 still comprised about $20 \%$ of the amount estimated for FMA 1, no coarse woody debris was maintained in FMAs 4 and 5. Also the mean number of trees with $>60 \mathrm{~cm}$ dbh showed the same trend. In contrast, the stands in FMAs 4 and 5 consisted of slightly more midsize trees, with $>40 \mathrm{~cm}$ dbh compared to the other management alternatives, while the number of big trees, which are more important for biodiversity, was more abundant in FMAs 1 and 2.

\section{Overview across services}

In the principal component analysis, FMAs 1 and 5 are separated and constitute the extremes on the PC1-axis, whereas FMAs 2, 3, and 4 are rather similar on PC1, but clearly separated on PC2 (Fig. 3, upper panel). The PC1 axis mainly represents opposite gradients in production and biodiversity and the PC2 represents differences related to water and nutrients (Fig. 3, lower panel).

\section{DISCUSSION}

\section{Productivity and economic value}

The resulting merchantable wood volume productivity of the FMAs differed from the yield quality assumed for simulation according to local yield tables. The yield, which was $8 \mathrm{~m}^{3} \mathrm{ha}^{-1}$ $\mathrm{yr}^{-1}$ for beech and $13 \mathrm{~m}^{3} \mathrm{ha}^{-1} \mathrm{yr}^{-1}$ for spruce, was estimated in yield tables for a reference rotation of 100 years. The actual rotation length for each FMA was about 15 to 20 years shorter for spruce than this reference rotation of 100 years and as much as 15 to 20 years longer for beech. In addition to this rotation length-related effect, the stand density regime within the FMAs influenced volume productivity of spruce and beech (Pretzsch 2004, Skovsgaard and Vanclay 2008). The lower volume of spruce within FMA 3 relative to FMA 4 (MAI 11 vs. $14 \mathrm{~m}^{3} \mathrm{ha}^{-1} \mathrm{yr}^{-1}$ ) most likely occurred because of the heavy crop tree oriented thinnings (heavy release of crop trees), which was demonstrated with empirical data (Herbstritt et al. 2006). These productivity figures were related to one generation only and thus are a conservative estimate for the
Fig. 3. Results of the principal component analysis based on a subset of Table 3 indicators. Upper panel: the differences between FMAs across all considered functions could be summarized in two dimensions, with PC1 explaining 66\% of the variation in the indicator set, and PC2 explaining 20\%. Lower panel: the PC loadings of the individual indicators grouped for each service-productive functions (diamond), carbon (triangle), nutrients/acidification (shaded square), water (open diamond), and biodiversity (dot).

Abbreviations of the factor loadings: $\left(\mathrm{MAI}_{\mathrm{u}}\right)$ mean annual increment; $\left(\mathrm{LEV}_{2 \%}\right)$ and $\left(\mathrm{LEV}_{5 \%}\right)$ land expectation value at $2 \%$ and $\left.5 \% ; \mathrm{C}_{\text {live }}\right),\left(\mathrm{C}_{\text {dead }}\right)$, and $\left(\mathrm{C}_{\text {harv }}\right) \mathrm{C}$ stock in living, dead, and harvested biomass; $\left(\mathrm{P}_{\text {bal }}\right) \mathrm{P}$ balance; $\left(\mathrm{Bc}_{\text {harv }}\right)$ acidification due to harvesting; $\left(\mathrm{N}_{\text {acid }}\right)$ potential acidification due to nitrate leaching; $\left(\mathrm{H}_{2} \mathrm{O}\right)$ water runoff; $\left(\mathrm{NO}_{3}-\right)$ nitrate in runoff; (FWD and CWD) fine and coarse woody debris; $\left(\mathrm{T}_{60}\right)$ trees with $>60 \mathrm{~cm} \mathrm{dbh}$; and $\left(\mathrm{T}_{\mathrm{SP}}\right)$ number of tree species.
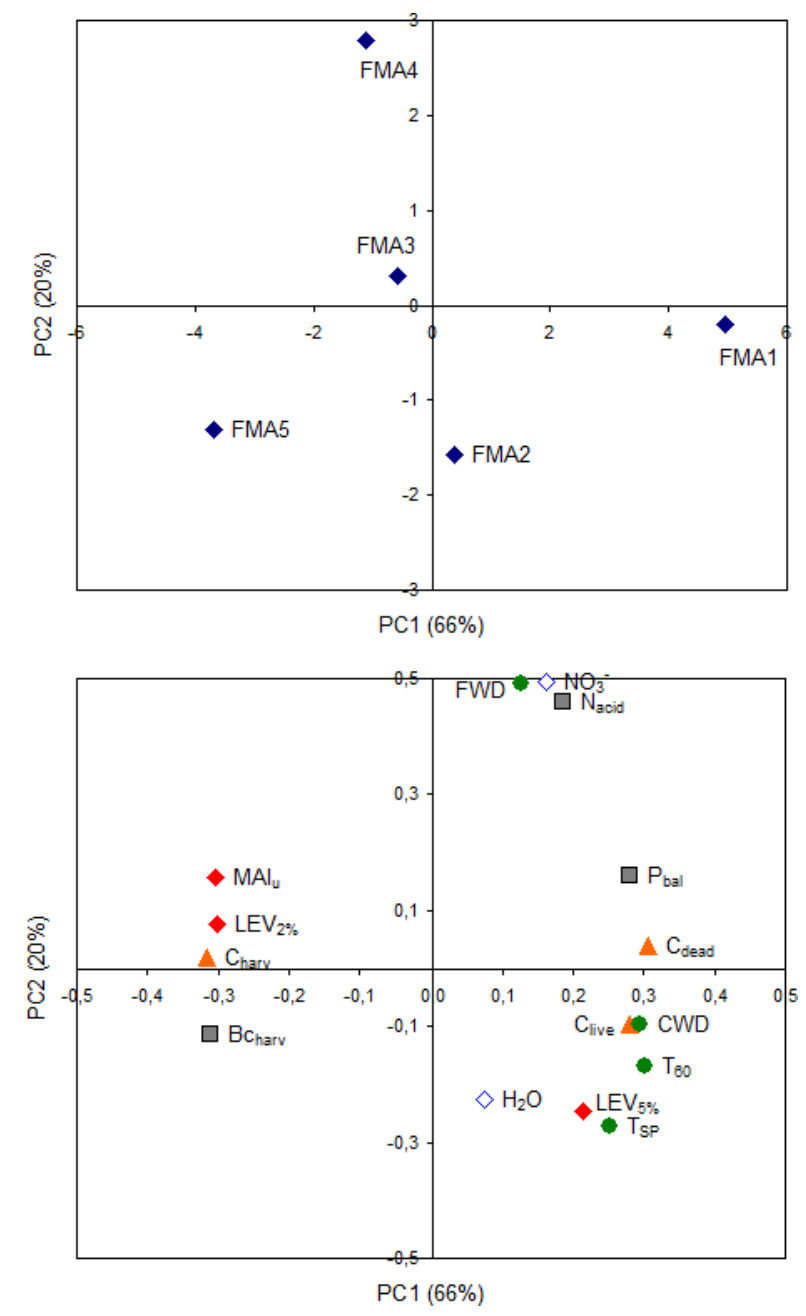
estate level. The prolonged regeneration cuttings in FMAs 2 and 3 (with natural regeneration occurring under the canopy) led to overlapping generations. This effect increased the mean annual volume production at the forest estate level to $11.3 \mathrm{~m}^{3}$ $\mathrm{ha}^{-1} \mathrm{yr}^{-1}$ within the managed part of beech FMA 2, as well as to $10.8 \mathrm{~m}^{3} \mathrm{ha}^{-1} \mathrm{yr}^{-1}$ for beech and $12.6 \mathrm{~m}^{3} \mathrm{ha}^{-1} \mathrm{yr}^{-1}$ for spruce in FMA 3 (Assmann 1965).

Besides the discussed effect on volume productivity, the rotation length strongly influenced land expectation value through consideration of interest rates. Ideally, mean length of rotation coincides with the point of land expectation value culmination. The simulated mean rotation lengths for the FMAs were close to the point in time of land expectation value culmination at an interest rate of $3 \%$. However, they were about 15 to 20 years past this point at an interest rate of $5 \%$. However, this effect did not change the ranking of the FMAs.

To calculate land expectation value, net timber revenues had to be assumed. The assumed revenues were estimated on the basis of observed prices for the period 1995 to 2005 for medium-quality wood at roadside. As such, they comprise conservative estimates for the assortment value of the crop trees in FMAs 2 and 3. Particularly for beech, crop tree oriented thinning approaches resulted in increased amounts of high quality timber (Hein et al. 2007). For spruce the same effect has to be assumed, but to a lesser extent. Although net revenues were stagnating for trees $>50 \mathrm{~cm} \mathrm{dbh}$, it is noteworthy that the management approach for spruce within FMA 3 resulted in the highest land expectation value, i.e., 7,100, down to $298 €$ $\mathrm{ha}^{-1}$ for interest rates from $2 \%$ up to $5 \%$. This finding is well in line with economic comparisons of alternative approaches for spruce, revealing the advantage of crop tree oriented approaches (Kohnle and von Teuffel 2004). When only beech is considered, FMA2 results in higher land expectation values at interest rates of 2 to $5 \%$ than FMA3, although it does include $20 \%$ set-aside areas. However, regardless of which interest rate is applied, beech management never reaches the potential land expectation value associated with spruce.

Next to cash flows from thinning and harvesting operations, costs for stand establishment influenced land expectation value. In the case of spruce, land expectation value was higher in FMA 3 where no regeneration costs were assumed, compared to FMA 4 which assumed regeneration costs of $2,300 € \mathrm{ha}^{-1}$. The differences in land expectation value allowed a hypothetical expenditure of $1,160 € \mathrm{ha}^{-1}$ for stand establishment in FMA 3 at an interest rate of 1\%, and even $2,440 € \mathrm{ha}^{-1}$ at $5 \%$, until the land expectation values of FMA 4 were achieved. The small differences emphasized the importance of a successful natural regeneration for FMA 3.

\section{Carbon}

The carbon stocks in living and dead biomass found in the reserve in this study were of the same magnitude as found in an assessment of a Danish seminatural beech forest (Vesterdal and Christensen 2007). Likewise, the carbon stocks of living and dead biomass were also of the same magnitude as found in conventional nemoral forests (Callesen et al. 2003). In contrast to carbon stock, the highest amount of carbon was extracted from the intensive FMAs, illustrating a clear tradeoff between storage within and export from the system (Fig. 4). Whether storing carbon in the system or exporting it best serves global carbon balances and impacts on climate depends on the fate of exported carbon. Exported carbon that substitutes for fossil fuels in energy production or is stored in permanent products will have strong positive impacts on climate change. In essence, oxidation of woody material can take place in the forest for the benefit of biodiversity and ecosystem services, including having positive effects on soil quality, or, for example, in a power plant as a $\mathrm{CO}_{2}$ - neutral energy source serving other human needs.

Fig. 4. Carbon in harvested products versus average carbon storage in above-ground living and dead biomass for the five forest management approaches (FMA).

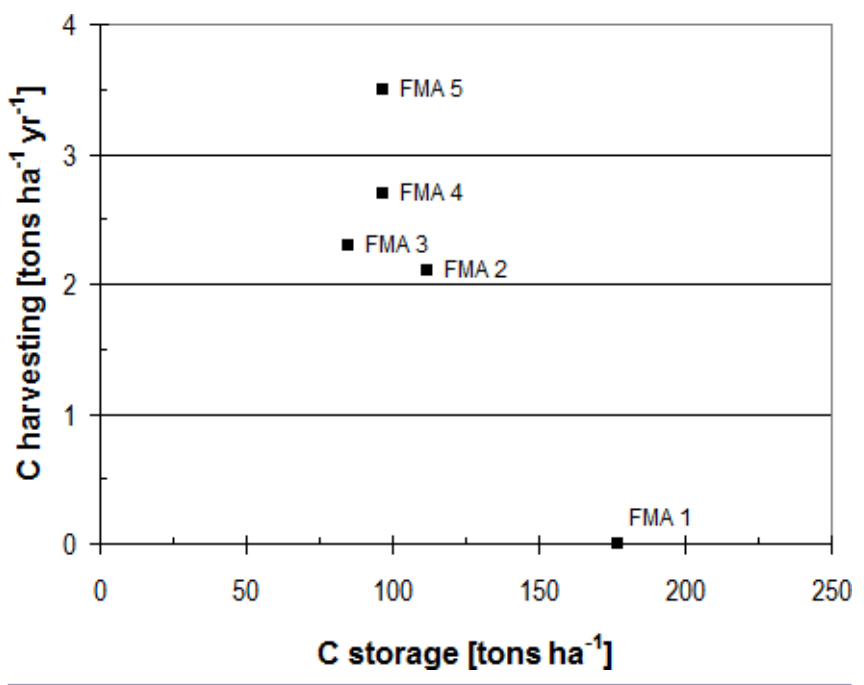

Carbon stocks in the soil were not considered in this study. In a recent review, Nave et al. (2010) documented a significant decrease in soil carbon following harvesting. The effect was most pronounced in the forest floor and more scattered in the mineral horizons. Generic modeling seems to support a significant decrease in soil carbon stores following intensive harvesting (Paul et al. 2003, Johnson et al. 2010). In our virtual study it must also be expected that soil carbon decreases as a result of harvesting, especially in the very intensive FMA 5.

\section{Water}

At the scale of a "normal forest" the FMA effects were leveled out to a great extent. So the differences in runoff for the FMAs were quite unspectacular. There was a clear difference between the coniferous forest FMAs with higher water 
consumption and the broadleaf-dominated FMAs with higher runoff (runoff is defined as total water surplus, independent of water pathways). When comparing the results with other studies on beech and spruce e.g., from Solling (Benecke 1984) under similar climatic conditions, one has to be aware, that in our virtual case study the higher consumption of pole stage and mature spruce stands was partly compensated by higher runoff in the clearcut stage. The nature reserve had an intermediate position. Continuous cover and high interception rates of coarse woody debris were, most likely, responsible for this response.

The fact, that the generic model approach showed low differences for our virtual forest must not be generalized. In case of a dry continental climate, even a difference in seepage of $70 \mathrm{~mm} / \mathrm{yr}$ would have a relatively pronounced impact on groundwater formation. Under such conditions transpiration rates may be even higher.

To simplify the $\mathrm{N}$ balance calculations, we assumed that in an $\mathrm{N}$ rich soil no further $\mathrm{N}$ is accumulated in soil organic matter (i.e., assuming steady state in soil $\mathrm{N}$ ). More importantly, we neglected the gaseous losses by nitrification/denitrification, which may amount to several $\mathrm{kg} \mathrm{N} \mathrm{ha}^{-1} \mathrm{yr}^{-1}$ as observed at the Högelwald site in southwestern Germany (Kreutzer et al. 2009). However, our estimated nitrate concentrations (1.2 to $3.3 \mathrm{mg} \mathrm{N}^{-1}$, Table 3), based on the simplified N-balance, are in the same range as concentrations observed at monitoring plots in the region that we exemplified. ${ }^{3}$ The estimated nitrate concentrations (Table 3 ) were relatively low across the FMAs despite the relatively high $\mathrm{N}$ deposition in the region. With precipitation at $>1000 \mathrm{~mm}$, high nitrate concentration over longer periods would be unlikely. However, had the precipitation been $650 \mathrm{~mm}$, FMAs 1 and 4 would have had nitrate concentrations above the drinking water standard. Although the nitrate concentration per se was low, the estimated $\mathrm{N}$ leaching (i.e., the $\mathrm{N}$ surplus of 6 to $18 \mathrm{~kg} \mathrm{~N} \mathrm{ha}^{-1}$ $\mathrm{yr}^{-1}$, Table 3) was high for managed forests in Europe (Dise et al. 2009) and implies a soil acidification of 0.4 to $1.3 \mathrm{keqv}$ $\mathrm{ha}^{-1} \mathrm{yr}^{-1}$, which is similar to that caused by biomass removal (Table 3). The marked reduction in $\mathrm{N}$ surplus going from FMA 4 to FMA 5 illustrates the possibility of counteracting the effects of $\mathrm{N}$ saturation by increasing biomass removal. This may be an option on fertile sites where base cations are in ample supply, or at sites where nutrients are recycled by wood ash recycling.

\section{Nutrients and acidification}

Nutrients will be accumulated in the soil or leached when inputs due to deposition exceed export caused by harvesting. Conversely, export in biomass exceeding deposition has to be compensated by a release from the soil taking place either as weathering or as a decrease in pools available for plant uptake (Raulund-Rasmussen et al. 2008). In our virtual study we had an excess of nitrogen combined with the shortage of the other elements; a similar situation has been found in other scenarios in northern Europe (Raulund-Rasmussen et al. 2008)

Acidification processes due to air pollution and harvesting have been studied intensively (Raulund-Rasmussen et al. 2008). In this study, we estimated the contribution coming from biomass harvesting and the acidification resulting from nitrate leaching. In all alternatives, nitrogen excess and leaching potentially caused a significant contribution to acidification, and only for the very intensive harvesting alternative (FMA 5) was the contribution from biomass export more important. This relatively high importance of nitrogen excess is of course due to the high deposition rate of nitrogen (Table 2). In acid soils, high leaching rates of nitrate may lead to mobilization of aluminum and therefore to the export of acidity (Gundersen et al. 2006).

\section{Biodiversity}

It is to be noticed that the applied mortality model resulted in a conservative measure for deadwood because it is sensitive only to stand density and tree dimension. Accordingly, the effects of bark beetles, storms, or snow breakages were not accounted for. However, these models do provide a sound "bottom-up" calculation (Lexer et al. 2000) of meaningful biodiversity indicators at the stand level (Lindenmayer et al. 2000). For contrasting the FMAs, these models and corresponding biodiversity attributes are considered most practical because at this level forest management is predominantly acting through the application of silvicultural operations (Smith et al. 2008). Other important aspects of biodiversity, including connectivity of forest stands and heterogeneity in size and spatial arrangement, need to be considered at the landscape level. This had required us to make additional assumptions because the simulations were based on a model that worked at both the tree level and the stand level.

The decrease in attributes of biodiversity with increasing management intensity is obvious. Two conclusions could be drawn from this. First, if the goal is to create opportunities for all species to survive in the landscape, it is necessary to set aside some areas for conservation purposes. There are qualities in FMA 1 that were lacking in FMA 2, and in order to facilitate dispersal and long-term survival, larger and coherent areas are in general better than small, isolated set-asides. However, the importance of these factors varies depending on the type of organism considered (Cabeza and Moilanen 2003). Separate and discrete populations might be beneficial for conserving biodiversity in some cases, e.g., if biotic agents such as diseases, or abiotic events such as extreme weather conditions, occur and locally eradicate the target organism. Second, even if some biodiversity values were lost, the FMA 2 scenario showed that it is possible to combine conservation of important factors for biodiversity with positive economic output. In this scenario important biodiversity values are maintained as well as a high land expectation value at a high interest rate. This 
Fig. 5. Multiple use of the forest management approaches (FMA) in timber production and nontimber services. Production is expressed as land expectation value (LEV) at an interest rate of 1\% (at left) and 3\% (at right) in monetary terms, woody debris measured in physical terms is provided as a surrogate for biodiversity. Further, the amount of the coarse woody debris is provided in brackets beside the labeling of the points. As a crude estimate, specialized management at the landscape level is superior at an interest rate of $1 \%$ (FMA 4 contains only fine woody debris). In contrast, at a $3 \%$ interest rate, multiple-use approaches are beyond the dotted regulatory line between specialized approaches.
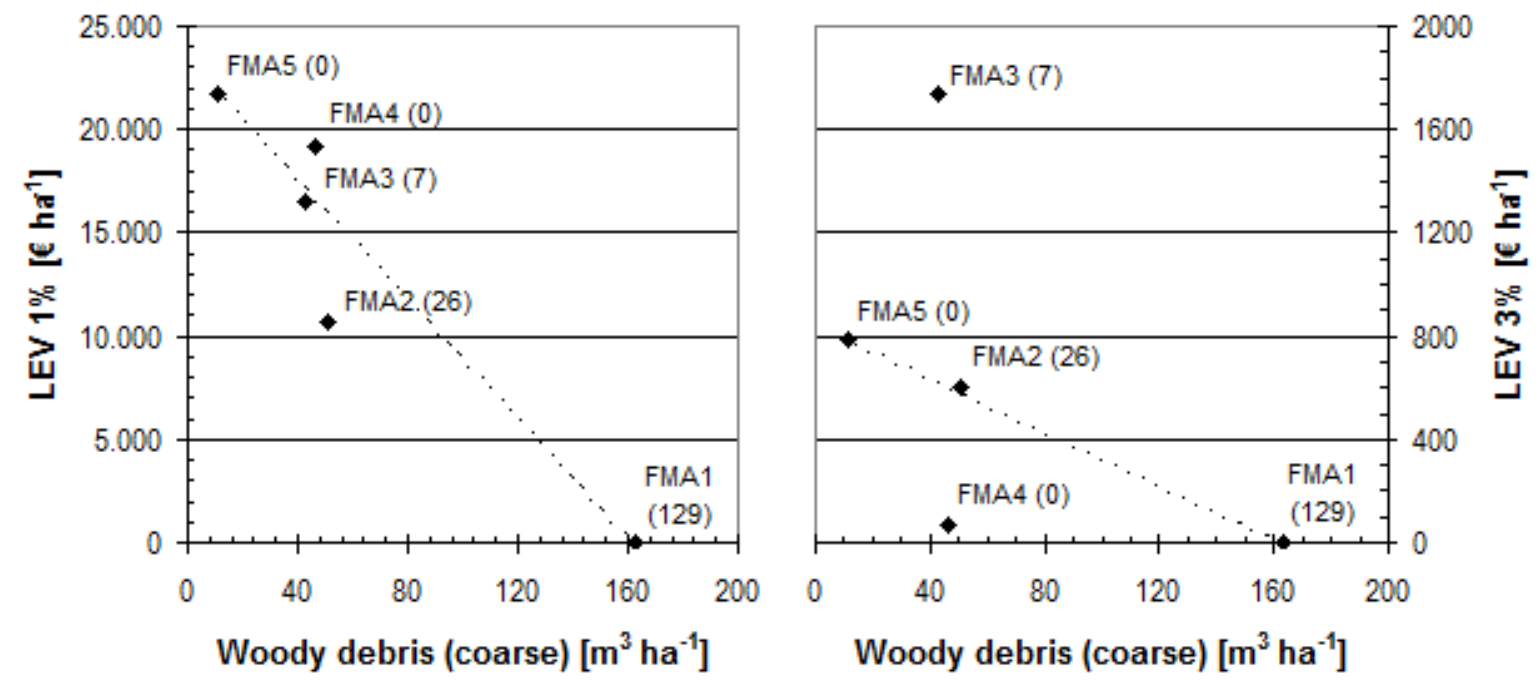

finding is supported by similar results for boreal (Hynynen et al. 2005) and temperate forests (Seidl et al. 2007).

\section{Synergism and trade-offs}

Under the assumed framework conditions, the selection of an FMA that maximized the economic value was dominated by interest rate. If this value is considered to be isolated, FMA 5 was the best choice at $1 \%\left(\mathrm{LEV}_{\text {low }}\right)$, followed by FMA 3 at $3 \%$, and FMA 2 - or even FMA 1 - at higher rates $\left(\mathrm{LEV}_{\text {high }}\right)$. These approaches intervene into natural processes at decreasing intensity from FMA 5 to FMA 2. Consequently, all other forest ecosystem services responded as well, because they were influenced by tree species composition, stand density, and age structure, or by import and export of nutrients as well.

Overall our results demonstrate that FMAs influenced the considered ecosystem services in different ways (Table 3, Fig. $3)$. However a major fraction of the variability $(66 \%)$ in the selected indicators was summarized in PC1 (Fig. 3, lower panel) meaning that for many indicators there were synergies (symbols clustering) and for others there were trade-offs (symbols opposed to each other on the PC1 (or PC2) axis). Some examples of synergies and trade-offs are further explored below.
The high management intensity of FMAs 4 and 5 negatively impacted all considered biodiversity attributes, revealing the well-known trade-off between maximum volume production and the maintenance of biodiversity at the stand level (Seymour and Hunter 1992, Seymour et. al. 1999, Hunter 2001, Boscolo and Vincent 2003, Gamborg and Larsen 2003). However, it was shown that maximum volume production does not necessarily coincide with the highest land expectation value. Depending on the interest rate, our low-intervention forestry, targeted to produce less volume but of high quality, resulted in high monetary values. Those are associated with uncertainties because they are calculated under framework conditions that are subject unknown to changes over time. In FMA 2 biodiversity attributes were still negatively affected compared to FMA 1, but they were considerably higher compared to more intense alternatives. This clearly reveals the need to consider synergies and trade-offs between market and nonmarket services at a selected interest rate. Fig. 5 shows the land expectation values achieved with interest rates of $1 \%$ and $3 \%$, as well as the mean amount of woody debris. The amount of coarse woody debris is additionally provided in brackets beside the labeling of the points in the figure. The straight regulatory line in Fig. 5 connects the two outermost FMAs that best fulfill one of the services. With the exception of FMA 
4 which produces high amounts of fine woody debris, the other FMAs remain below this line at a low interest rate. Thus, a specialized approach is superior. To achieve the desired levels of both services, the required landscape mixture of specialized approaches can be selected along this line. However, at an interest rate of 3\%, FMAs 2 and 3 are beyond this line, thus proposing a convex possibility frontier. This effect of interest rate is also indicated by the findings of Boscolo and Vincent (2003), Hynynen et al. (2005), and Seidl et al. (2007) for different forest types. Although interest rate had a strong influence on land expectation value, the ranking of different management alternatives for oak and pine forests in a temperate region of eastern Germany under priority settings of stakeholder groups in overall utility was not sensitive to variations in interest rate (Fürstenau et al. 2007). However, the highest interest rate considered by Fürstenau et al. (2007) was $2.5 \%$. Possibly, this explains why the described effect of interest rate on the ranking of management alternatives in our study does not become apparent. In accordance with the desired level of achievement, an integrative approach will synergistically best maintain biodiversity while providing the highest economic result. It raises rather more the questionwhich attribute level is to be maintained while providing income from timber production.

Similarly, the effects on the carbon stock and sequestration were different, and at least need to be seen as twofold. Firstly, the highest stock and $\mathrm{C}$ assimilation rate were found in the untouched reserve (FMA 1) where the harvesting rate is zero, and because we have defined the alternative as a steady state reference, the assimilated carbon was (almost completely) released again due to respiration and decomposition. Secondly and conversely, the managed alternatives-especially the intensive FMA 5-all show high harvesting rates of C. At first glance these results seem to be in contrast to Seidl et al. (2007) leading to the result that the unmanaged reference has the highest in situ $\mathrm{C}$ sequestration (comparable to our $\mathrm{C}$ stock). However, while we used a steady state assumption, Seidl et al. (2007) used the same starting point, and probably therefore came to the same high changes in the stock. In parallel to our results, they find trade-offs between biodiversity and production.

This study clearly illustrated the complex synergy and tradeoff patterns between production and the other ecosystem services, and within the other ecosystem services. Despite the complexity, the main differences in services provision could be separated into two dimensions (Fig. 3) which illustrates that the synergies and trade-offs in management decisions can probably be clarified, especially as the response function for the services becomes better established. The patterns obtained here may not be as generally consistent as the assumed input variables such as costs and timber prizes, and natural conditions may change the resulting indicators for the services significantly. However, the study shows that using a combination of conceptual, empirical, and process models is a sound way to develop a basis for the management decision process.

In the case of conflicting objectives, segregating specialized forest management by forest service at the landscape level might be appropriate. With regard to the maintenance of biodiversity, one possibility might be to set aside nature reserves with strict protection. To achieve this without reducing the timber harvest requires a compensatory increase in harvest elsewhere. Where such an increase in timber yield is possible, timber lost from setting aside landscape in nature reserves could be replaced by timber from a small area of land dedicated to intensive production. Embedded in a predominant matrix of forest management intensity, this forms the vision of a landscape triad as formulated for Maine (Seymour and Hunter 1992, Seymour 1993). This vision intrinsically implies that there is no best single solution that combines all services. However, one problem with this strategy is that large areas are required to conserve viable populations, and that nature reserves eventually become isolated islands in the landscape (Whittaker et al. 2001). In addition, identified responses of ecosystem services to silvicultural operations enable managers to integrate appropriate conservation measures in forest management approaches (Kulhavý et al. 2004). In the case of preserving biodiversity this might include the retention of habitat elements such as coarse woody debris or veteran trees (Lindenmayer et al. 2000) and emulation of natural disturbances (Bengtsson et al. 2000). Also, maintaining soil and water quality requires a reduction of nutrient losses, e.g., through harvesting of stemwood only instead of whole tree harvesting (Raulund-Rasmussen et al. 2008). In the case of nitrogen saturation, surplus nitrogen may, however, be removed with biomass to decrease nitrate pollution of seepage water.

${ }^{1}$ The weather data were obtained from Deutscher Wetterdienst for climate station 330 Beerfelden, and from Forstliche Versuchs- und Forschungsanstalt Baden-Württemberg for climate station 460 Heidelberg.

${ }^{2}$ Amounts were based on typical amounts in the region as assessed at station 204 Heidelberg run by Forstliche Versuchsund Forschungsanstalt Baden-Württemberg.

${ }^{3}$ Amounts were based on typical amounts in the region as assessed at Level II plot 802 Heidelberg run by Forstliche Versuchs- und Forschungsanstalt Baden-Württemberg.

Responses to this article can be read online at: http://www.ecologyandsociety.org/issues/responses. $\mathrm{php} / 5066$ 


\section{Acknowledgments:}

The research for this article was executed as part of the EFORWOOD integrated project funded under the EU 6th Framework Programme for Research, Technological Development and Demonstration, Priority 1.1.6.3. Global Change and Ecosystems (European Commission, DG Research, contract 518128 (GOCE)). The financial support of the European Commission is gratefully acknowledged. We wish to acknowledge Klaus von Wilpert of the Forstliche Versuchs- und Forschugsanstalt Baden Württemberg for kindly providing us with deposition and soil data from Level II plot 802 Heidelberg. We would like to thank the anonymous referees for useful comments on an earlier version of this paper.

\section{LITERATURE CITED}

Assmann, E. 1961. Waldertragskunde: Organische Produktion, Struktur, Zuwachs und Ertrag von Waldbeständen. Bayerischer Landwirtschaftsverlag, München, Germany.

Benecke, P. 1984. Der Wasserumsatz eines Buchen- und eines Fichtenwaldökosystems in Hochsolling. Schriften der Forstlichen Fakultät Göttingen und der Niedersächsischen Forstlichen Versuchsanstalt 77(158), Germany.

Bengtsson, J., S. G. Nilsson, A. Franc, and P. Menozzi. 2000. Biodiversity, disturbances, ecosystem function and management of European forests. Forest Ecology and Management 132:39-50. http://dx.doi.org/10.1016/S0378-1127. (00)00378-9

Boscolo, M., and J. R. Vincent. 2003. Nonconvexities in the production of timber, biodiversity, and carbon sequestration. Journal of Environmental Economics and Management 46:251-268. http://dx.doi.org/10.1016/S0095-0696(02)00034-7

Bredahl Jacobsen, J., B. Möhring, and C. Wippermann. 2004. Business economics of conversion and transformation-a case study of Norway spruce in northern Germany. Pages 225-252 in H. Spiecker, J. Hansen, E. Klimo, J. P. Skovsgaard, H. Sterba, and K. von Teuffel, editors. Norway spruce conversion: options and consequences. European Forest Institute Research Report 18. Brill Academic Publishers, Leiden, The Netherlands.

Cabeza, M., and A. Moilanen. 2003. Site-selection algorithms and habitat loss. Conservation Biology 17(5):1402-1413. http://dx.doi.org/10.1046/j.1523-1739.2003.01421.x

Callesen, I., J. Liski, K. Raulund-Rasmussen, M. T. Olsson, L. Tau-Strand, L. Vesterdal, and C. J. Westman. 2003. Soil carbon stores in Nordic well-drained forest soilsrelationships with climate and texture class. Global Change Biology 9:358-370. http://dx.doi.org/10.1046/j.1365-2486.2003.00587. $\underline{\mathrm{X}}$
Dise, N. B., J. J. Rothwell, V. Gauci, C. van der Salm, and W. de Vries. 2009. Predicting dissolved inorganic nitrogen leaching in European forests using two independent databases. Science of the Total Environment 407:1798-1808. http://dx. doi.org/10.1016/j.scitotenv.2008.11.003

Duncker, P. S., S. M. Barreiro, G. M. Hengeveld, T. Lind, W. L. Mason, S. Ambrozy, and H. Spiecker. 2012. Classification of forest management approaches: a new conceptual framework and its applicability to European forestry. Ecology and Society 17(4): 51. http://dx.doi.org/10.5751/ES-05262-170451

Duncker, P., and J. Zell. 2009. Die Auswirkung der Berücksichtigung von Nebenzielen auf den Kapitalwert der Baden-Württembergischen Fichtenwälder. Pages 191-199 in J. Nagel, editor. 2009. Sektion Ertragskunde: Beiträge zur Jahrestagung 2009. Deutscher Verband Forstlicher Forschungsanstalten, Göttingen, Germany.

Eckmüllner, O. 2006. Allometric relations to estimate needle and branch mass of Norway spruce and Scots pine in Austria. Austrian Journal of Forest Science 123:7-16.

Eckmüllner, O., and H. Sterba. 2000. Crown condition, needle-mass and sapwood area relationships of Norway spruce (Picea abies L. KARST.). Canadian Journal of Forest Research 30:1646-1654.

Elderton, W. P., and N. L. Johnson. 1969. Systems offrequency curves. Cambridge University Press, Cambridge, UK. http:// dx.doi.org/10.1017/CBO9780511569654

Ellenberg, H. 1996. Vegetation Mitteleuropas mit den Alpen in ökologischer, dynamischer und historischer Sicht. Ulmer, Stuttgart, Germany.

Failing, L., and R. Gregory. 2003. Ten common mistakes in designing biodiversity indicators for forest policy. Journal of Environmental Management 68:121-132. http://dx.doi. org/10.1016/S0301-4797(03)00014-8

Faustmann, M. 1849a. Berechnung des Werthes, welchen Waldboden, sowie noch nicht haubare Holzbestände für die Waldwirthschaft besitzen. Allgemeine Forst- und Jagdzeitung 1849:441-455.

Faustmann, M. 1849b. On the determination of the value which forest land and immature stands possess for forestry. In M. Gane, editor. Martin Faustmann and the evolution of discounted cash flow. Commonwealth Forestry Institute Paper No. 42. University of Oxford, Oxfordshire, England. (Translated by W. Linnard in 1968, from Allgemeine Forstund Jagd-Zeitung.) (Translation republished in Journal of Forest Economics 1(1):7-44 (1995).)

Federer, C. A. 1995. BROOK90: a simulation model for evaporation, soil water, and streamflow. Version 3.1 Computer Freeware and Documentation. USDA Forest Service, Durham, New Hampshire, USA. 
Forest Europe. 1993. Resolution H1, general guidelines for the sustainable forest management of forests in Europe, 16-17 June 1993, Helsinki, Finland. Second Ministerial Conference on the Protection of Forests in Europe, Madrid, Spain.

Fürstenau, C., F. W. Badeck, P. Lasch, M. J. Lexer, M. Lindner, P. Mohr, and F. Suckow. 2007. Multiple-use forest management in consideration of climate change and the interests of stakeholder groups. European Journal of Forest Research 26:225-239. http://dx.doi.org/10.1007/s10342-006-0114$\underline{\mathrm{X}}$

Gamborg, C., and J. B. Larsen. 2003. 'Back to nature'-a sustainable future for forestry? Forest Ecology and Management 179:559-571.

Gundersen, P., I. Callesen, and W. de Vries. 1998. Nitrate leaching in forest ecosystems is related to forest floor $\mathrm{C} / \mathrm{N}$ ratios. Environmental Pollution 102:403-407. http://dx.doi. org/10.1016/S0269-7491(98)80060-2

Gundersen, P., I. K. Schmidt, and K. Raulund-Rasmussen. 2006. Leaching of nitrogen from temperate forests-effects of air pollution and forest management. Environmental Reviews 56:1-57. http://dx.doi.org/10.1139/a05-015

Gustafsson, L., J. De Jong, and M. Norén. 1999. Evaluation of Swedish woodland key habitats using red-listed bryophytes and lichens. Biodiversity and Conservation 8:1101-1114. http://dx.doi.org/10.1023/A:1008934526658

Hasenauer, H. 2006. Sustainable forest management: growth models for Europe. Springer, Berlin, Heidelberg, Germany.

Hein, S., E. Lenk, J. Klädtke, and U. Kohnle. 2007. Z-Baum orientierte Auslesedurchforstung in Buche (Fagus sylvatica L.): Auswirkung auf Qualität, Sortenstruktur und Wertleistung. Allgemeine Forst- und Jagdzeitung 178 (1):8-20.

Helmisaari, H.-S., K. H. Hanssen, S. Jacobson, M. Kukkola, J. Luiro, A. Saarsalmi, P. Tamminen, and B. Tveite. 2011. Logging residue removal after thinning in Nordic boreal forests: long-term impact on tree growth. Forest Ecology and Management 261(11):1919-1927. http://dx.doi.org/10.1016/ j.foreco.2011.02.015

Herbstritt, S., U. Kohnle, P. Abetz, and G. Kenk. 2006. The European stem number experiment in Norway spruce (Picea abies (L.) Karst.). 3. Report. IUFRO Working Party 1.05.05 "Thinning Experiments". Berichte Freiburger Forstliche Forschung, Heft 66. Forstliche Versuchs- und Forschungsanstalt Baden-Württemberg, Freiburg, Germany.

Hietz, P., O. Eckmüllner, and H. Sterba. 2010. Leaf area of beech (Fagus sylvatica L.) from different stands in eastern Austria studied by randomized branch sampling. European Journal of Forest Research 129(3):401-408.
Hunter, M. L. 2001. Maintaining biodiversity in forest ecosystems. Cambridge University Press, Cambridge, UK. http://dx.doi.org/10.1017/CBO9780511613029

Hynynen, J., A. Ahtikoski, J. Siitonen, R. Sievänen, and J. Liski. 2005. Applying the MOTTI simulator to analyse the effects of alternative management schedules on timber and non-timber production. Forest Ecology and Management 207:5-18. http://dx.doi.org/10.1016/j.foreco.2004.10.015

Jacobsen, C., P. Rademacher, H. Meesenburg, and K. J. Meiwes. 2002. Gehalte chemischer Elemente in Baumkompartimenten. Literaturstudie und Datensammlung, Göttingen, Germany.

Johnson, K. D., F. N. Scatena, and Y. Pan. 2010. Short and long-term responses of total soil organic carbon to harvesting in a northern hardwood forest. Forest Ecology and Management 259:1262-1267. http://dx.doi.org/10.1016/j. foreco.2009.06.049

Jost, G., G. B. M. Heuvelink, and A. Papritz. 2005. Analysing the space-time distribution of soil water storage of a forest ecosystem using spatio-temporal kriging. Geoderma 128 (3-4):258-273. http://dx.doi.org/10.1016/j.geoderma.2005.04.008

Katzensteiner, K. 2000. Wasser- und Stoffhaushalt von Waldökosystemen in den nördlichen Kalkalpen. Forstliche Schriftenreihe der Universität für Bodenkultur, Wien, Austria.

Knigge, W., and H. Schulz. 1966. Grundriß der Forstbenutzung. Paul Parey Verlag, Hamburg und Berlin, Germany.

Kohnle, U., and K. von Teuffel. 2004. Ist die Produktion von Fichten-Starkholz noch zeitgemäß in Baden-Württemberg? Ertragsvergleich von vier Modellen zur Produktion von starkem und mittelstarkem Holz. Allgemeine Forst- und Jagdzeitung 175(9):171-182.

Kreutzer, K., K. Butterbach-Bahl, H. Rennenberg, and H. Papen. 2009. The complete nitrogen cycle of a N-saturated spruce forest ecosystem. Plant Biology 11:694-700. http://dx. doi.org/10.1111/j.1438-8677.2009.00236.x

Kulhavý, J., T. Berger, V. Èaboun, A. Gottlein, B. Grunda, R. Heitz, P. Kantor, E. Klimo, B. Lomský, S. Niemtur, K.-E. Rehfuess, M. Slodič́ák, H. Sterba, and L. Vesterdal. 2004. Ecological consequences of conversion. Pages 165-195 in H. Spiecker, J. Hansen, E. Klimo, J. P. Skovsgaard, H. Sterba, and K. von Teuffel, editors. Norway spruce conversion: options and consequences. European Forest Institute Research Report 18. Brill Academic Publishers, Leiden, The Netherlands.

Landesforstverwaltung Baden-Württemberg. 1993. Hilfstabellen für die Forsteinrichtung: Zusammengestellt für den Gebrauch in der Landesforstverwaltung. Ministerium für Ländlichen 
Raum, Ernährung Landwirtschaft und Forsten BadenWürttemberg, Stuttgart, Germany.

Larsson, T.-B. 2001. Biodiversity evaluation tools for European forests. Ecological Bulletins 50:1-237.

Lasch, P., F. W. Badeck, F. Suckow, M. Lindner, and P. Mohr. 2005. Model-based analysis of management alternatives at stand and regional level in Brandenburg (Germany). Forest Ecology and Management 207:59-74. http://dx.doi. org/10.1016/j.foreco.2004.10.034

Lexer, M. J., and R. T. Brooks. 2005. Decision support for multiple purpose forestry. Forest Ecology and Management 207:1-3. http://dx.doi.org/10.1016/j.foreco.2004.11.002

Lexer, M. J., W. Lexer, and H. Hasenauer. 2000. The use of forest models for biodiversity assessment at stand level. Investigación Agraria, Sistemas y Recursos Forestales 2000 No. Fuera de Serie 1:297-316.

Lindenmayer, D., C. Margules, and D. Botkin. 2000. Indicators of biodiversity for ecologically sustainable forest management. Conservation Biology 14(4):941-950. http://dx. doi.org/10.1046/j.1523-1739.2000.98533.x

Merganičová, K., S. A. Pietsch, and H. Hasenauer. 2005. Testing mechanistic modelling to assess impacts of biomass removal. Forest Ecology and Management 207:37-57. http:// dx.doi.org/10.1016/j.foreco.2004.10.017

Millennium Ecosystem Assessment. 2005. Ecosystems and human well-being: synthesis. Island Press, Washington, DC, USA.

Nave, L. E., E. D. Vance, C. W. Swanston, and P. S. Curtis. 2010. Harvest impacts on soil carbon storage in temperate forests. Forest Ecology and Management 259:857-866. http:// dx.doi.org/10.1016/j.foreco.2009.12.009

Nunery, J. S., and W. S. Keeton. 2010. Forest carbon storage in the northeastern United States: net effects of harvesting frequency, post-harvest retention, and wood products. Forest Ecology and Management 259:1363-1375. http://dx.doi. org/10.1016/j.foreco.2009.12.029

Paul, K. I., P. J. Polglase, J. G. Nyakuengama, and P. K. Khanna. 2003. Changes in soil carbon following afforestation. Forest Ecology and Management 168:241-257. http://dx.doi. org/10.1016/S0378-1127(01)00740-X

Peterken, G. F. 1996. Natural woodland: ecology and conservation in northern temperate regions. Cambridge University Press, Cambridge, UK.

Pretzsch, H. 2004. Gesetzmäßigkeit zwischen Bestandesdichte und Zuwachs. Lösungsansatz am Beispiel von Reinbeständen aus Fichte (Picea abies [L.] Karst.) und Buche (Fagus sylvatica L.). Allgemeine Forst- und Jadgzeitung 175 (12):225-234.
Pretzsch, H. 2009. Forest dynamics, growth and yield: from measurement to model. Springer-Verlag, Berlin and Heidelberg, Germany.

Pukkala, T. 2002. Multi-objective forest planning. Kluwer, Dordrecht, The Netherlands. http://dx.doi.org/10.1007/3-54$\underline{0-31304-4 \_17}$

Raulund-Rasmussen, K., I. Stupak, N. Clarke, I. Callesen, H. S. Helmisaari, E. Karltun, and I. Varnagiryte-Kabasinskiene. 2008. Effects of very intensive forest biomass harvesting on short and long term site productivity. Pages 29-78 in D. Röser, A. Asikainen, K. Raulund-Rasmussen, I. Stupak, editors. Sustainable use of forest biomass for energy. Springer, Dordrecht, The Netherlands. http://dx.doi.org/10.1007/978-$\underline{1-4020-5054-13}$

Ruddell, S., R. Sampson, M. Smith, J. Giffen, J. Hagan, D. Sosland, J. Godbee, J. Heissenbuttel, S. Lovett, J. Helms, W. Price, and R. Simpson. 2007. The role of sustainably managed forests in climate change mitigation. Journal of Forestry 105:314-319.

Seidl, R., W. Rammer, D. Jäger, W. S. Currie, and M. J. Lexer. 2007. Assessing trade-offs between carbon sequestration and timber production within a framework of multi-purpose forestry in Austria. Forest Ecology and Management 248:64-79. http://dx.doi.org/10.1016/j.foreco.2007.02.035

Seymour, R. S. 1993. Plantations or natural stands? Options and tradeoffs for high-yield silviculture. Pages 16-32 in R. D. Briggs, and W. B. Krohn, editors. Nurturing the northeastern forest: proceedings of a joint meeting of the New England Society American Foresters and Maine Chapter of the Wildlife Society, March 3-5, 1993, Portland, Maine. Maine Agricultural and Forestry Experiment Station Miscellaneous Report 382. Cooperative Forestry Research Unit, University of Maine, Orono, Maine, USA.

Seymour, R. S., and M. L. Hunter. 1992. New forestry in eastern spruce-fir forests: principles and applications to Maine. Maine Agricultural and Forestry Experiment Station Miscellaneous Publication 716. Cooperative Forestry Research Unit, University of Maine, Orono, Maine, USA.

Seymour, R. S., and M. L. Hunter. 1999. Principles of ecological forestry. Pages 22-61 in M. Hunter, editor. Maintaining biodiversity in forested ecosystems. Cambridge University Press, Cambridge, UK. http://dx.doi.org/10.1017/ CBO9780511613029.004

Skovsgaard, J. P., and J. K. Vanclay. 2008. Forest site productivity: a review of the evolution of dendrometric concepts for even-aged stands. Forestry 81(1):13-31. http:// dx.doi.org/10.1093/forestry/cpm041

Smith, G. F., T. Gittings, M. Wilson, L. French, A. Oxbrough, S. O’Donoghue, J. O’Halloran, D. L. Kelly, F. J. G. Mitchell, 
T. Kelly, S. Iremonger, A. M. McKee, and P. Giller. 2008. Identifying practical indicators of biodiversity for stand-level management of plantation forests. Biodiversity and Conservation 17:991-1015. http://dx.doi.org/10.1007/ $\underline{\text { s10531-007-9274-3 }}$

Sprugel, D. G. 1991. Disturbance, equilibrium, and environmental variability: what is 'natural' vegetation in a changing environment? Biological Conservation 58:1-18.

Sterba, H. 1988. Increment losses by full-tree-harvesting in Norway spruce (Picea abies). Forest Ecology and Management 24:283-292. http://dx.doi.org/10.1016/0378-1127. (88)90105-3

Straka, T. J., and S. H. Bullard. 1996. Land expectation value calculation in timberland valuation. Appraisal Journal 64 (4):399-405.

Vesterdal, L., and M. Christensen. 2007. The carbon pools in a Danish semi-natural forest. Ecological Bulletins 52:113-122.

Weise, U., and E. Kublin. 1997. Distanzunabhängiges Wachstumsmodell zur Optimierung der Behandlung von Fichtenbeständen. 259-278 in Sektion Ertragskunde: Beiträge zur Jahrestagung 1997 in Grünberg. Deutscher Verband Forstlicher Forschungsanstalten. Göttingen, Germany.

Weise, U., and E. Kublin. 1998. Modellierung langfristiger Wachstumsabläufe von Fichtenbeständen. Allgemeine Forst Zeitschrift - Der Wald 53:422-423.

Weslien, J., L. Finér, J. A. Jónsson, H. Koivusalo, A. Laurén, T. Ranius, and B. D. Sigurdsson. 2009. Effects of increased forest productivity and warmer climates on carbon sequestration, runoff water quality and accumulation of dead wood in a boreal landscape: a modelling study. Scandinavian Journal of Forest Research 24:333-347. http://dx.doi. org/10.1080/02827580903085171

Wirth, C., J. Schumacher, and E. D. Schulze. 2004. Generic biomass functions for Norway spruce in Central Europe-a meta-analysis approach toward prediction and uncertainty estimation. Tree Physiology 24:121-139. http://dx.doi. org/10.1093/treephys/24.2.121

Whittaker, R. J., K. J. Willis, and R. Field. 2001. Scale and species richness: towards a general, hierarchical theory of species diversity. Journal of Biogeography 28:453-470. http:// dx.doi.org/10.1046/j.1365-2699.2001.00563.x

Wutzler, T., C. Wirth, and J. Schumacher. 2008. Generic biomass functions for common beech (Fagus sylvatica) in central Europe: predictions and components of uncertainty. Canadian Journal of Forest Research 38:1661-1675. http:// dx.doi.org/10.1139/X07-194
Yue, C., U. Kohnle, and S. Hein. 2008. Combinin tree- and stand-level models: a new approach to growth prediction. Forest Science 54:553-566.

Zanella, A., B. Jabiol, J. F. Ponge, G. Sartori, R. De Waal, B. Van Delft, U. Graefe, N. Cools, K. Katzensteiner, H. Hager, and M. A. Englisch. 2011. European morpho-functional classification of humus forms. GEODERMA 164 (3-4):138-145. http://dx.doi.org/10.1016/j.geoderma.2011.05.016

Zell, J., G. Kändler, and M. Hanewinkel. 2009. Predicting constant decay rates of coarse woody debris-a meta-analysis approach with a mixed model. Ecological Modelling 220:904-912. http://dx.doi.org/10.1016/j.ecolmodel.2009.01.020

Erratum: There were errors in Figures 4 and 5 of the original publication of this paper. The correction was made on 11 January 2012. 